\title{
WAS THE EXPANSION OF HOUSING CREDIT IN JAPAN GOOD OR BAD?
}

Charles Yuji Horioka

Yoko Niimi

January 2020

The Institute of Social and Economic Research

Osaka University

6-1 Mihogaoka, Ibaraki, Osaka 567-0047, Japan 


\title{
Was the Expansion of Housing Credit in Japan Good or Bad?
}

\author{
Charles Yuji Horioka* \\ Research Institute for Economics and Business Administration, Kobe University; Asian \\ Growth Research Institute; Osaka University; and National Bureau of Economic \\ Research \\ Yoko Niimi \\ Doshisha University and Asian Growth Research Institute
}

January 2020

\begin{abstract}
This paper shows, using data from the Family Income and Expenditure Survey, that housing credit has become increasingly available over time in Japan, especially since 2000 , and that this has made it easier for Japanese households to purchase housing and enabled them to do so at an earlier age. However, it also shows that the greater availability of housing credit has increased households' housing loan repayment burden, which has resulted in their cutting back on their other consumption expenditures and created the potential for retirement insecurity. Another concern is that the increasing availability of housing credit has been accompanied by a pronounced shift from fixed-rate to variablerate housing loans. This is cause for concern given the low level of financial literacy that prevails among the Japanese population and the likelihood that interest rates on variablerate housing loans will be raised sooner or later as monetary policy is tightened.
\end{abstract}

Keywords: Homeownership; Housing credit; Housing loans; Mortgages; Household debt; Household liabilities

JEL classification codes: D14, E21, R21

*Corresponding author: Charles Yuji Horioka, Research Institute for Economics and Business Administration, Kobe University, 2-1, Rokkodai-cho, Nada-ku, Kobe, Hyogo 657-8501, JAPAN. Email address: horioka@rieb.kobe-u.ac.jp 


\section{Introduction}

Financial sector development (in particular, the expansion of housing credit) is generally regarded as being a good thing because it relaxes the borrowing constraints facing households, makes it easier for them to purchase housing and enabling them to purchase housing at a younger age. However, the overexpansion of housing credit can cause serious problems for individual households as well as for the economy as a whole.

The best example of this is the subprime mortgage crisis that occurred in the United States (US) in 2007-10. Starting in the late 1990s, financial institutions in the US greatly expanded their supply of subprime mortgages (housing loans to borrowers with low credit ratings that typically charged a fixed interest rate for an initial period and a variable interest rate thereafter). The overuse of subprime mortgages caused a surge in defaults and foreclosures, which triggered the financial crisis of 2007-08 and the subsequent Great Recession (2007-09) (see, for example, Dynan and Kohn (2007), Gerardi et al. (2008), Sanders (2008), and Whalen (2008)). ${ }^{1}$ In addition, Lusardi et al. (2018a, 2018b, forthcoming) have documented how the overexpansion of housing credit and other forms of consumer credit has created a situation in which many Americans are approaching retirement with significant amounts of debt, threatening their retirement security.

There has been a similar expansion of housing credit in Japan, particularly since 2000. It is of interest to know whether or not it caused, or can be expected to cause, a crisis akin to the subprime mortgage crisis in the US. The purpose of this paper is to shed light on the extent of the expansion of housing credit in Japan and on the possible impacts of this expansion on the financial well-being of households using data from the Family Income and Expenditure Survey, a household survey conducted by the Japanese government. The ultimate objective of the paper is to assess whether the expansion of housing credit was a good thing or a bad thing. To the best of our knowledge, this is the first detailed analysis of this issue for the case of Japan although Horioka and Niimi (forthcoming) conducted a preliminary analysis using only stock data on liabilities.

\footnotetext{
1 A comprehensive analysis of the causes of the subprime mortgage crisis in the US is beyond the scope of this paper, but the consensus is that it was caused not only by the sharp increase in the supply of housing debt to risky borrowers but also by the increase in housing speculation including increased purchases of secondary homes for investment purposes, the collapse of the housing bubble, and inadequate government regulation of financial products such as mortgage-backed securities and collateralized debt obligations that distributed and perhaps concealed the risk of mortgage default (refer to the papers cited above for more details).
} 
The remainder of this paper is organized as follows. Section 2 presents a history of housing credit in Japan; section 3 discusses the data used for the analysis; section 4 documents the rapid growth in the availability of housing credit in Japan after 2000; sections 5 and 6 present evidence on the benefits and costs of the increasing availability of housing credit, respectively; and section 7 summarizes, concludes, and explores the policy implications of our findings.

\section{The History of Housing Credit in Japan}

The Second World War caused the destruction of a substantial fraction of Japan's housing stock, and as a result, housing conditions were poor and the homeownership rate was low at the end of the war. One of the policies that the Japanese government adopted to remedy this situation was to establish in 1950 the Government Housing Loan Corporation (GHLC, in Japanese, Juutaku Kin'yuu Kouko), a government agency similar to the Federal Housing Authority in the US, whose purpose was to provide long-term fixed- and lowinterest rate loans to households wishing to purchase or construct housing. In the early postwar years, the GHLC was the primary source of housing loans, but private financial institutions began offering housing loans in the 1970s and 1980s. Moreover, in 1994, the Ministry of Finance liberalized the housing loan market and allowed private financial institutions to freely set the terms and interest rates of housing loans. This led to an expansion in the amount of housing credit provided by private financial institutions, and it came to be felt that there was no longer a need for the government to supply housing credit.

It was therefore decided in 2001 that the GHLC would be abolished as part of the reform of special public corporations, and in 2003, a law governing the restructuring of the GHLC was passed that provided for the abolition of the GHLC in 2007 and its replacement by the newly created Japan Housing Finance Agency (JHF, in Japanese, Juutaku Kin'yuu Shien Kikou). At the same time, it was decided that the GHLC would scale back its provision of housing loans and shift its focus to securitizing and guaranteeing private-sector housing loans. The GHLC started its securitization operations in 2003, and these operations were taken over by the JHF following the abolition of the GHLC in 2007.

This meant that, whereas the primary role of the GHLC had been to provide housing loans 
directly to households, the JHF's primary role is to help private financial institutions to provide housing loans by securitizing and guaranteeing a type of long-term fixed-rate housing loan offered by private financial institutions called Flat 35 (a fixed-rate housing loan with a maturity of 35 years). More specifically, the JHF purchases such housing loans from private financial institutions, issues mortgage-backed securities, and guarantees that investors in these securities will receive payment of the principal and interest on schedule. The government decided to assume the role of securitizing and guaranteeing private housing loans because, although the securitization of housing loans started in 1999, the securitization market for private label securities was too small to replace GHLC lending.

The end result of these reforms is that the housing finance system was greatly liberalized, with the role of the private sector expanding relative to that of the government sector and with the choices available to households broadening to include not only fixed-rate loans but also variable-rate loans and elective-period fixed rate loans, a hybrid product whose interest rate is fixed for a pre-determined number of years before becoming variable. Figure 1, for example, shows the shares of various types of housing loans in the case of new lending during the 2001-16 period. One of the most noticeable trends in this figure is a significant increase in the share of variable-rate loans since the mid-2000s. Its share was only about $23 \%$ in 2001 but increased to about $50 \%$ in 2016 .

Moreover, other factors also contributed to the expansion of housing credit such as the decline in corporate borrowing and the need for lenders to find alternate borrowers for their funds. ${ }^{2}$

To summarize, recent reforms of the housing credit system have not only increased the supply of housing credit available to households but have also increased the choices available to them. In conjunction with the low interest rates that have prevailed in recent years, these reforms have made it easier for households to purchase a home (see Kobayashi (2016) and Yamori and Kondo (2008) for more details).

\footnotetext{
${ }^{2}$ Note that, in addition to factors increasing the supply of housing credit, there were also factors increasing the demand for housing credit. For example, Yukutake et al. (2015) suggest that inter vivos transfers from parents to children may have become more exchange-related (i.e., tied to care of elderly parents) over time, which in turn may have made children more hesitant to rely on parents for financial assistance and induced them to rely more on housing loans when purchasing housing.
} 


\section{Data}

The data we use in this paper are taken from the Family Income and Expenditure Survey (FIES). This survey, the Japanese equivalent of the US Consumer Expenditure Survey, is a household survey conducted on an ongoing basis by the Statistics Bureau, Ministry of Internal Affairs and Communications. It collects extensive information on household income, consumption, saving, wealth, and liabilities. About 8,000 households are randomly selected from throughout Japan using a three-stage stratified sampling method, and thus the sample of the FIES is representative of the entire population of Japan.

Until 2001, stock data on wealth and liabilities were collected separately in a companion survey called the Family Savings Survey (FSS), and thus, until 2001, stock data on wealth and liabilities are taken from this source. The FSS was fully incorporated into the FIES in 2002, and the data for 2001 and earlier and those for 2002 and later are fully comparable.

These surveys collect data on all households, but in this analysis, we present data only on salaried worker households (households in which the household head is a salaried worker) because data on income and saving are not available for other households (primarily selfemployed, unemployed, and retired households). Moreover, we confine our sample to two-or-more-person households due to data limitations.

\section{The Expansion of Housing Credit in Japan}

The liberalization of the housing loan market that has taken place since the 1990s is likely to have resulted in the increasing availability of housing credit over time, as noted earlier. To confirm this trend, we look at stock data on the ratio of housing-related debt to household disposable income. Note that, in this section as well as throughout the remainder of this paper, we present data on the full sample of two-or-more-person salaried worker households of all ages as well as on such households with a head aged 30-39, 4049, and 50-59 for selected years during the 1970-2017 period. $^{3}$

\footnotetext{
3 We do not show data on households with a head aged 29 or younger because the number of observations is too small to be reliable. We do not show data on households with a head aged 60 or older either because the compulsory retirement age for salaried workers in Japan has traditionally been 60 , meaning that the vast majority of those aged 60 or older are already retired and, as a result, the number of observations with a head aged 60 or older in our sample (i.e., the sample of salaried worker households) is too small to be reliable.
} 
Table 1 shows stock data on the ratio of housing-related debt to household disposable income for the 1970-2017 period. ${ }^{4}$ As can be seen from this table, this ratio was a mere 11 to $14 \%$ in 1970, but it increased sharply for all age groups during the 1970-2017 period. The increase was especially pronounced for the 30-39 age group, increasing by 4.85 percentage points per year, on average, for this age group as opposed to 2.77 percentage points for the full sample, 3.45 percentage points for the 40-49 age group, and 1.74 percentage points for the 50-59 age group.

Looking in more detail at trends over time, the rate of increase in the housing debt-toincome ratio was roughly constant throughout the 1970-2017 period for the full sample, averaging 2.68 percentage points per year during the 1970-2000 period and 2.91 percentage points during the $2000-17$ period. However, we find that the rate of increase in the housing debt-to-income ratio varied greatly over time if we look at trends by age group. For example, in the case of the 30-39 age group, the housing debt-to-income ratio increased by 3.07 percentage points per year, on average, during the 1970-2000 period but by 7.98 percentage points during the $2000-17$ period. By contrast, it increased by 3.96 (2.05) percentage points per year during the 1970-2000 period but by 2.55 (1.19) percentage points during the $2000-17$ period for the 40-49 (50-59) age group. Thus, the increase in the housing debt-to-income ratio accelerated after 2000 in the 30-39 age group but decelerated after 2000 in the 40-49 and 50-59 age groups. This suggests not only that the availability of housing credit increased rapidly over time but that it became available to younger and younger households over time.

\section{The Benefits of the Increasing Availability of Housing Credit in Japan}

In the previous section, we provided evidence that housing credit has become increasingly available especially after 2000 and especially for the 30-39 age group. In this section, we attempt to shed light on what impact the increasing availability of housing credit has had on household behavior. One possibility is that the increasing availability of housing credit has allowed households to purchase housing with a smaller down payment, making it easier for households to purchase housing and enabling them to do so at an earlier age than previously. We present three types of evidence in support of this working hypothesis.

Table 2 shows flow data on the ratio of new housing loans to housing purchases (commonly referred to as the loan-to-value ratio), which indicates the proportion of

${ }^{4}$ See Horioka (2012) for earlier data on this ratio. 
housing purchases financed by housing loans, or to put it another way, one minus the down payment ratio. As can be seen from this table, the loan-to-value ratio was only about 11 to about $43 \%$ for all age groups in 1970 but increased sharply thereafter (except for a few outliers for the 40-49 and 50-59 age groups, which are presumably due to the small number of households purchasing a new house). For example, it increased from about 37 to about $72 \%$ for the full sample and from about 43 to $85 \%$ for the $30-39$ age group. These figures imply that the down payment ratio decreased sharply from about 63 to about $28 \%$ for the full sample and from about 57 to about $15 \%$ for the $30-39$ age group.

Looking in more detail at trends over time, the rate of increase in the loan-to-value ratio (the decrease in the down payment ratio) accelerated after 2000 for both the full sample and the 30-39 age group. The rate of increase averaged $0.51(0.07)$ percentage points per year during the 1970-2000 period but accelerated to 1.19 (2.35) percentage points during the 2000-17 period for the full sample (the 30-39 age group). These figures provide further corroboration that housing credit became much more available during this period, especially after 2000 and especially for the 30-39 age group, and suggest that the amount of down payment required for purchasing housing has been declining over time.

We look next at stock data on the homeownership rate (Table 3) and flow data on the ratio of housing purchases to household disposable income (Table 4). Table 3 presents data on the homeownership rate for the 1975-2017 period (data were not available for 1970). According to this table, the homeownership rate increased sharply during this period for all age groups (with the exception of the $1975-95$ period in the case of the 30-39 age group), from about 56 to about $79 \%$ for the full sample, from about 48 to about $62 \%$ for the 30-39 age group, from about 65 to about $79 \%$ for the $40-49$ age group, and from about 76 to about $87 \%$ for the $50-59$ age group. These figures suggest that the government's efforts to improve the housing conditions of the Japanese population have been effective, at least to some extent.

Looking in more detail at trends over time, the rate of increase in the homeownership rate was roughly constant throughout the 1975-2017 period for the full sample, averaging 0.48 percentage points per year during the $1975-2000$ period and 0.62 percentage points during the 2000-17 period. However, trends over time varied greatly by age group. The homeownership rate of the 30-39 age group decreased by 0.15 percentage points per year, on average, during the 1970-2000 period, but it increased by 1.06 percentage points during the $2000-17$ period. By contrast, the homeownership rate of the 40-49 (50-59) age 
group increased by $0.44(0.37)$ percentage points per year during the $1970-2000$ period, but the rate of increase decelerated to $0.21(0.14)$ percentage points during the 2000-17 period.

As a result, the rate of increase in the homeownership rate was much higher for the 4049 and 50-59 age groups than for the 30-39 age group during the 1970-2000 period, whereas the opposite was the case during the 2000-17 period. Note also the fact that the homeownership rate increased more rapidly for the 30-39 age group than for the 40-49 and 50-59 age groups during the 2000-17 period dramatically decreased the gap in the homeownership rate between these age groups. The homeownership rate of the 30-39 age group was 31.4 (40.4) percentage points lower than that of the 40-49 (50-59) age group in 2000 , but this gap had narrowed by almost half to 16.9 (24.8) percentage points by 2017.

Turning next to data on housing purchases as a ratio of household disposable income, Table 4 shows data on this ratio for the 1970-2017 period. The housing purchases-toincome ratio was in the 1.6 to $2.9 \%$ range for all age groups in 1970 and showed little variation by age, but subsequent trends in this ratio vary greatly by age group. It declined during the 1970-2017 period by 0.01 percentage points per year, on average, for the full sample, by 0.02 percentage points for the $40-49$ age group, and by 0.06 percentage points for the 50-59 age group, but it increased by 0.11 percentage points for the 30-39 age group. Moreover, the rate of increase of this ratio for the 30-39 age group accelerated sharply over time from 0.04 percentage points per year during the $1970-2000$ period to 0.22 percentage points during the $2000-17$ period.

As a result, in 2017, the housing purchases-to-income ratio was by far the highest for the 30 -39 age group (7.5\%), much higher than for the 40-49 age group $(0.5 \%)$ and the 50-59 age group $(0.3 \%)$. This trend, together with the trend in homeownership rates shown in Table 3, suggests that housing purchases have become increasingly concentrated in the 30-39 age group over time.

Further corroboration of the trend toward purchasing housing at a younger age is provided by Table 5 . The table shows data on the life-cycle pattern of the housing debt-to-income ratio by birth cohort and is based on the information contained in Table 1. According to this table, the housing debt-to-income ratio increases with age for birth cohorts born in 1936-45 or earlier but peaks in the 40-49 age group for birth cohorts born in 1946-55 or 
later. This change occurred because younger birth cohorts were able to purchase housing at a younger age than older birth cohorts, meaning that they could repay their housing loans and reduce their outstanding housing debt sooner.

All of these findings corroborate the working hypothesis we proposed at the beginning of this section that the increasing availability of housing credit has made it easier for households to purchase housing and has enabled them to do so at an earlier age (in their 30s) than previously.

Needless to say, however, the increase in housing purchases in the 30-39 age group after 2000 was not due entirely to the increasing availability of housing credit. There were other contributing factors, and we briefly discuss each of these factors in turn.

(1) Tax breaks for housing purchase. The Japanese government has offered various tax breaks for housing purchase since 1978, partly to promote homeownership and partly to stimulate the economy as a whole. These tax breaks have typically taken the form of tax deductions that are calculated as a certain percentage (currently 1\%) of the outstanding value of housing loans and that are available for a certain number of years (formerly 10 years but extended to 13 years on October 1, 2019, to coincide with the consumption tax increase) if certain conditions are met. Given that these tax breaks for housing purchase have been repeatedly expanded, they are likely to have promoted housing purchases as well as the use of housing loans to finance these purchases.

(2) Monetary policy. The Bank of Japan has maintained an expansionary monetary policy since at least September 1995, and in particular, it has pursued a so-called 'zero interest rate policy' since February 1999 (except during the August 2000 to March 2001 period). This led to a sharp decline in all interest rates, and interest rates on housing loans were no exception. Moreover, the Bank of Japan has pursued quantitative easing policies since 2001 and quantitative and qualitative easing policies since 2013, and this has increased the supply of credit, including housing credit. The decline in interest rates and the increased supply of credit are likely to have promoted housing purchases as well as the use of housing loans to finance these purchases.

(3) The reduction in company housing and rent subsidies. In the past, large Japanese companies provided low-cost company housing and/or rent subsidies to their employees, and the government did likewise for its workers, but both have been 
scaling back such fringe benefits in recent years. For example, a survey by Keidanren (Japan Business Federation) found that the housing-related subsidies of large companies peaked in 1996 and have been steadily declining since $2000 .^{5}$

(4) The decline in the construction of public housing. One pillar of the Japanese government's housing policy during the postwar period (together with subsidized housing loans) was the provision of public housing, largely to the low- and middleincome and the elderly. However, the construction of public housing has largely been curtailed since the 1990s, and this may have contributed to the increase in housing purchases in recent years (see, for example, Xu and Zhou (2019)).

(5) The decline in land prices. Real land prices in Japan rose sharply in the late 1980s, but they have been declining steadily since 1992, and the decline in land prices undoubtedly contributed to the increase in housing purchases by making housing more affordable (see Horioka and Niimi (2020) for data on trends in land prices over time). ${ }^{6}$

(6) The trend toward nuclear families. The social norm in Japan has traditionally been for children (especially the eldest son) to continue living with their parents even after they marry and have children and to care for elderly parents. However, there has been a steady increase in the share of nuclear families in recent decades (see, for example, Niimi (2016)), and this trend may have increased the need for the younger generation to secure its own housing, thereby contributing to the increase in housing purchases.

In sum, all of these factors have undoubtedly played some role in encouraging households to purchase housing and to finance their purchases using housing loans and in encouraging them to do so at an earlier age since 2000 . A rigorous analysis is needed to determine the contribution of each of these factors to the recent increase in housing purchases among young households.

\footnotetext{
5 Refer to Keizai Dantai Rengoukai (Keidanren) (Japan Business Federation), Dai-62-kai Fukuri Kousei-hi Chousa Kekka Houkoku (62 ${ }^{\text {nd }}$ Report on the Results of the Employee Benefits Survey) (Fiscal Year 2017), December 19, 2018 (available at https://www.keidanren.or.jp/policy/2018/115.html).

6 Note, however, that Nemoto (2017) finds that land prices are significantly affected by credit availability, which suggests that land prices are endogenous and that the increased availability of housing credit during the late 1980s was one cause of the surge in land prices during this period.
} 


\section{The Costs of the Increasing Availability of Housing Credit in Japan}

We have so far shown that the increasing availability of housing credit has been beneficial to households, making it easier for them to purchase housing and enabling them to do so at an earlier age than previously. However, we now wish to consider whether the increasing availability of housing credit has imposed any offsetting costs on households. One possibility is that increased purchases of housing at younger ages has increased the debt burden of households and reduced their standard of living.

In order to test this hypothesis, Table 6 shows data on the ratio of housing loan repayments to household disposable income (hereafter called the housing loan repayment burden) during the 1970-2017 period. This ratio was only 0.8 to $1.4 \%$ in 1970 , but it has shown an upward trend since then for all age groups, increasing from $1.2 \%$ to $8.3 \%$ for the full sample, from 1.4 to $9.5 \%$ for the $30-39$ age group, from 1.3 to $10.0 \%$ for the $40-49$ age group, and from 0.8 to $8.0 \%$ for the $50-59$ age group.

Looking in more detail at trends over time, during the 1970-2000 period, the rate of increase of the housing loan repayment burden was highest for the 40-49 age group (0.29 percentage points per year, on average, as opposed to 0.21 percentage points for the full sample and $0.20(0.18)$ percentage points for the 30-39 (50-59) age group), but during the 2000-17 period, it was highest for the 30-39 age group (0.12 percentage points per year as opposed to 0.06 percentage points for the full sample and $-0.01(0.10)$ percentage points for the 40-49 (50-59) age group). The fact that the housing loan repayment burden increased most rapidly for the 40-49 age group during the 1970-2000 period but increased most rapidly for the 30-39 age group during the 2000-17 period reflects the decline in the average age of housing purchase over time.

Our finding that the housing loan repayment burden increased for all age groups during the 1970-2017 period, presumably as a result of increased housing purchases, suggests that households may have had to reduce their propensity to consume by the same extent. However, it must be borne in mind that homeowner households do not need to pay rent and that this benefit of homeownership at least partially offsets the burden of housing loan repayments and other expenses associated with homeownership. Hence, households' standard of living will not necessarily deteriorate as a result of increased housing purchases and the resulting increase in their housing loan repayment burden. 
In order to test this assertion, we need to examine data on the ratio of rent to disposable income, which are shown in Table 7 for the 1970-2017 period. The rent-to-income ratio was relatively low for all age groups in 1970 (about 1.2 to 3.5\%) but was somewhat higher for the 30-39 age group than for the 40-49 and 50-59 age groups. This can, at least partly, be explained by the fact that the homeownership rate was much lower for the 30-39 group, as shown in Table 3. The rent-to-income ratio subsequently showed an upward trend from 1975 until 2005-10 for all age groups (even though the homeownership ratio increased for all age groups except for the 30-39 age group (see Table 3)), presumably because rent levels increased during this period. However, the rent-to-income ratio tapered off after 2005-2010 for all age groups. This change in trend is particularly pronounced for the 3039 age group, for which the rate of change in the rent-to-income ratio was negative (-0.08 percentage points per year, on average) during the 2000-17 period. As shown earlier, the homeownership rate of the 30-39 age group increased sharply during this period, suggesting that the decreased rent burden was caused by the increase in homeownership. These findings suggest that households' standard of living may not necessarily have deteriorated due to the increased burden of housing loan repayments inasmuch as households no longer need to pay rent after purchasing housing.

In order to ascertain the extent to which the decline in rent payments has offset the increase in the housing loan repayment burden, we look next at data on the ratio of total housing-related expenditures (the sum of housing loan repayments and rent) to household disposable income for the 1970-2017 period (see Table 8). The housing-relatedexpenditure-to-income ratio was relatively low for all age groups in 1970 (between $2.0 \%$ and $4.8 \%$ ), but this ratio then showed a sharp upward trend in all age groups, increasing to the $9.8-14.5 \%$ range in 2017 . This suggests that the increased burden of housing loan repayments has not been fully offset by the reduced rent burden.

This, in turn, raises the question of whether the sharp increase in the total burden of housing-related expenditures required households, especially households in the 30-39 age group, to reduce their non-housing consumption. We therefore look at data on the nonhousing consumption propensity (calculated as the ratio of household consumption excluding rent to household disposable income) for the 1970-2017 period (see Table 9). As can be seen from this table, this ratio was relatively high and almost identical (about $77 \%$ ) in all age groups in 1970, but it declined for all age groups thereafter. Moreover, it declined much more sharply for the 30-39 age group than for older age groups, and as a result, it was much lower for the 30-39 age group than for older age groups by 2017 
(59.0\% vs. $64.1 \%$ for the $40-49$ age group and $73.0 \%$ for the $50-59$ age group). Thus, the increasing burden of housing-related expenditures required all households but especially households in the 30-39 age group to reduce their non-housing consumption. In the case of the 30-39 age group, the increase in the housing-related-expenditure-to-income ratio was 9.7 percentage points during the 1970-2017 period (see Table 8), while the decrease in the non-housing consumption propensity during the same period was 18.1 percentage points (see Table 9). Thus, the increase in the burden of housing-related expenditures can explain more than half of the decrease in non-housing consumption.

Another cause for concern is that Japanese households will not be able to accumulate enough assets for retirement due to the excessive burden of housing loan repayments. To investigate this possibility, we look at data on the ratio of financial assets net of nonhousing liabilities to household disposable income. We focus on financial assets rather than total assets because Japanese households typically continue living in their own homes after retirement, meaning that only financial assets can be used to finance their living expenses during retirement. Table 10 shows data on the so-called net financial asset ratio for the 1970-2017 period. This ratio increased throughout this period for the full sample and for the 50-59 age group but peaked in 1990-2005 (2000-05) for the 30-39 (4049) age group. Since the increase in the housing loan repayment burden after 2000 was highest for the 30-39 age group, it is quite possible that the tapering off of the net financial asset ratio after 2000 for this age group was due, at least in part, to the increase in its housing loan repayment burden (see Table 6).

To corroborate this hypothesis further, we show in Table 11 data on the life-cycle pattern of the net financial asset ratio by birth cohort, which is based on the information contained in Table 10. We find that the net financial asset ratio increases with age for all birth cohorts but that the rate of the increase has declined over time in recent years. For example, the increase in the net financial asset ratio from the 30-39 age group to the 40-49 age group was about 64 percentage points for the 1946-55 birth cohort but only about 36 percentage points for the 1966-75 birth cohort. Since the former figure pertains to the 1985-95 period while the latter figure pertains to the 2005-2015 period, the flattening in the age profile of the net financial asset ratio from cohort to cohort is presumably due, at least in part, to the increasing housing loan repayment burden after 2000 .

There is therefore a possibility that, as a result of their increasing housing loan repayment burden, birth cohorts born after 1960 (who are now 60 or younger) may not have enough 
resources to finance their living expenses during retirement. However, it must be borne in mind that homeowners have an important advantage vis-à-vis renters (namely, that they do not need to pay rent), as a result of which they do not need as much wealth to finance their living expenses during retirement.

Yet another cause for concern is that the increasing availability of housing credit over the last few decades has been accompanied by a significant shift from fixed-rate to variablerate housing loans (see Figure 1). As long as interest rates are kept low, this should not be a serious concern, but the Bank of Japan is likely to normalize its monetary policy sooner or later, and when it does so, interest rates on variable-rate housing loans will increase. Moreover, given that interest rates have been kept low for so long in Japan and given the low levels of financial literacy of Japanese households, many Japanese households may not be fully aware of the risks associated with variable-rate housing loans.

Figure 2, for example, shows that about $12 \%$ of those who have taken out variable-rate housing loans do not seem to understand the implications of interest rate increases for loan repayment amounts. In addition, about $37 \%$ of them are worried about whether or not they understand this risk sufficiently. This suggests that Japan may see a group of households who encounter difficulties in repaying their housing loans if and when interest rates are increased. It is indeed worrying to find that about one-fifth of those who have taken out variable-rate housing loans do not seem to have thought about possible ways of responding to the increase in the loan repayment amount that will occur if and when interest rates increase and that about $10 \%$ of such households plan to refinance when interest rates increase, which is the opposite of what they should do (see Figure 3).

\section{Summary, Conclusions, and Policy Implications}

There has been a rapid expansion of housing credit in Japan especially since 2000, and it is of interest to know whether or not it caused, or can be expected to cause, a crisis akin to the subprime mortgage crisis in the US. This paper tried to shed light on the extent of the expansion of housing credit in Japan and on the possible impacts of this expansion on the financial well-being of households using data from the Family Income and Expenditure Survey. The ultimate objective of the paper was to assess whether the expansion of housing credit was a good thing or a bad thing.

To summarize our main findings, we showed that housing credit has become increasingly 
available over time in Japan, especially since 2000, and that this has made it easier for Japanese households to purchase housing and has enabled them to do so at an earlier age, which in turn has freed them from the burden of having to pay rent. On the other hand, this has increased households' housing loan repayment burden and required them to cut back on their other consumption expenditures and created the potential for retirement insecurity. Furthermore, we showed that the increasing availability of housing credit has been accompanied by a significant shift from fixed-rate to variable-rate housing loans. This is cause for concern given the low level of financial literacy that prevails among the Japanese population and the likelihood that interest rates on variable-rate housing loans will be raised sooner or later as monetary policy is tightened.

The rapid expansion of housing credit in Japan therefore has not produced a crisis as it did in the US, at least not yet, but there is still cause for concern. At the very least, the government should monitor the debt levels and housing loan repayment burdens of households and provide them with adequate financial literacy so that they fully appreciate the risks inherent in variable-rate housing mortgages. Moreover, the government should monitor the situation with particular vigilance if and when the Bank of Japan normalizes its monetary policy because households have become more vulnerable to rising interest rates as the share of households who have chosen variable-rate housing loans has increased sharply in recent years.

Turning finally to the question we posed in the title of our paper "Was the expansion of housing credit in Japan good or bad?" we showed that it conferred considerable advantages on Japanese households such as making it easier for them to purchase housing and enabling them to do so at an earlier age, which in turn has freed them from the burden of having to pay rent, and these are significant advantages given Japanese households' strong preference for homeownership. The rapid expansion of housing credit has, at the same time, conferred disadvantages on Japanese households such as increasing their housing loan repayment burden, requiring them to cut back on their other consumption expenditures, and creating the potential for retirement insecurity, but none of these disadvantages appears to be very serious, at least at the present time. Thus, we believe that the advantages conferred by the rapid expansion of housing credit greatly offset the disadvantages thereof and that the answer to our question is an unqualified "yes." At the same time, however, we wish to reiterate our view that the impact of housing credit on households needs to be monitored closely to prevent the occurrence of a housing loan crisis similar to the one observed in the US. 


\section{Acknowledgements}

We are grateful to Joshua Aizenman, Anoshua Chaudhuri, Shin'ichi Fukuda, Soyoung Kim, Young Sik Kim, Jong-Wha Lee, Olivia Mitchell, John Sabelbaus, Koji Sakuma, Etsuro Shioji, Nobuyuki Yamori, other participants of the Asia-Pacific Economic Association Meeting at Fukuoka University and the Workshop on Trade, Development, and Inequality at Wuhan University, and especially an anonymous referee for their helpful comments and discussions and to the JSPS (Japan Society for the Promotion of Science) KAKENHI Grant Numbers $18 \mathrm{H} 00870$ and $15 \mathrm{H} 05728$ for its financial support. 


\section{References}

Dynan, K. E. and D. L. Kohn (2007), “The Rise in U.S. Household Indebtedness: Causes and Consequences," Finance and Economics Discussion Series, No. 2007-37, Washington, DC, US: Division of Research \& Statistics and Monetary Affairs, Federal Reserve Board.

Gerardi, K., A. Lehnert, S. M. Sherlund, and P. Willen (2008), "Making Sense of the Subprime Crisis," Brookings Papers on Economic Activity, 39(2): 69-159.

Horioka, C. Y. (2012), “Are Japanese Households Financially Healthy, If So, Why?” Japanese Economy, 39(4): 109-124.

Horioka, C. Y. and Y. Niimi (forthcoming), "Aging and Debt in Japan,” in O. S. Mitchell and A. Lusardi (eds.), Remaking Retirement: Debt in an Aging Economy. Oxford, UK: Oxford University Press, forthcoming.

Kobayashi, M. (2016), “The Housing Market and Housing Policies in Japan,” ADBI Working Paper Series, No. 558, Tokyo, Japan: Asian Development Bank Institute.

Lusardi, A., O. S. Mitchell, and N. Oggero (2018a), "The Changing Face of Debt and Financial Fragility at Older Ages," AEA (American Economic Association) Papers and Proceedings, 108: 407-411.

Lusardi, A., O. S. Mitchell, N. Oggero (2018b), "Understanding Debt at Older Ages and Its Implications for Retirement Well-being," Pension Research Council Working Paper, PRC WP2018-11, Philadelphia, PA: Pension Research Council, Wharton School, University of Pennsylvania.

Lusardi, A., O. S. Mitchell, and N. Oggero (forthcoming), "Debt and Financial Vulnerability on the Verge of Retirement," Journal of Money, Credit and Banking, forthcoming.

Nemoto, H. (2017), "Credit Availability and Asset Price: Empirical Analysis of the Japanese Bubbles in 1980s," Journal of the Japanese and International Economies, 44: 90-98.

Niimi, Y. (2016), "The 'Costs' of Informal Care: An Analysis of the Impact of Elderly Care on Caregivers' Subjective Well-being in Japan," Review of Economics of the Household, 14: 779-810.

Sanders, A. (2008), “The Subprime Crisis and Its Role in the Financial Crisis," Journal of Housing Economics, 17(4): 254-261.

Whalen, R. C. (2008), “The Subprime Crisis - Cause, Effect and Consequences," Journal of Affordable Housing and Community Development Law, 17(3): 219-235.

Xu, H., and Y. Zhou (2019), "Public Housing Provision and Housing Vacancies in Japan," 
Journal of the Japanese and International Economies, 53, Article 101038.

Yamori, N. and K. Kondo (2008), "How Has Japan Housing Finance Agency's Flat 35 Affected Regional Housing Loan Markets," Government Auditing Review, 15: 6376.

Yukutake, N., S. Iwata, and T. Idee (2015), "Strategic Interaction between Inter Vivos Gifts and Housing Acquisition," Journal of the Japanese and International Economies, 35: 62-77. 
Table 1: Ratio of Housing-related Liabilities to Household Disposable Income (percent)

\begin{tabular}{|c|c|c|c|c|}
\hline Year & Full sample & $30-39$ & $40-49$ & $50-59$ \\
\hline & & age group & age group & age group \\
\hline 1970 & 11.7 & 11.2 & 14.3 & 11.1 \\
\hline 1975 & 23.2 & 27.1 & 26.1 & 20.1 \\
\hline 1980 & 37.5 & 43.1 & 42.7 & 28.8 \\
\hline 1985 & 51.6 & 62.9 & 58.3 & 40.2 \\
\hline 1990 & 58.4 & 63.7 & 73.0 & 45.5 \\
\hline 1995 & 72.4 & 86.1 & 80.9 & 60.4 \\
\hline 2000 & 92.2 & 103.3 & 133.0 & 72.7 \\
\hline 2005 & 106.0 & 140.4 & 134.7 & 78.1 \\
\hline 2010 & 121.9 & 171.8 & 154.2 & 84.1 \\
\hline 2015 & 136.1 & 200.7 & 183.0 & 92.7 \\
\hline 2017 & 141.8 & 239.0 & 176.3 & 92.9 \\
\hline \multicolumn{5}{|c|}{ Average change per year (percentage points) } \\
\hline $1970-2000$ & 2.68 & 3.07 & 3.96 & 2.05 \\
\hline $2000-2017$ & 2.91 & 7.98 & 2.55 & 1.19 \\
\hline $1970-2017$ & 2.77 & 4.85 & 3.45 & 1.74 \\
\hline
\end{tabular}

Notes: The figures show the ratio of housing-related liabilities to household disposable income (percent).

Source: Family and Income Expenditure Survey, conducted by the Statistics Bureau, Ministry of Internal Affairs and Communications, Government of Japan (available at https://www.stat.go.ip/data/kakei/index3.html) 
Table 2: Loan-to-Value Ratio (percent)

\begin{tabular}{|c|c|c|c|c|}
\hline Year & Full sample & $30-39$ & $40-49$ & $50-59$ \\
\hline & & age group & age group & age group \\
\hline 1970 & 36.9 & 43.3 & 37.2 & 11.0 \\
\hline 1975 & 29.4 & 32.7 & 41.8 & 7.8 \\
\hline 1980 & 39.6 & 39.5 & 46.9 & 15.6 \\
\hline 1985 & 50.7 & 56.4 & 52.5 & 42.7 \\
\hline 1990 & 44.1 & 55.1 & 22.1 & 72.1 \\
\hline 1995 & 65.4 & 69.9 & 57.6 & 66.4 \\
\hline 2000 & 52.1 & 45.3 & 47.0 & 52.9 \\
\hline 2005 & 44.7 & 65.7 & 36.3 & 11.7 \\
\hline 2010 & 56.9 & 73.5 & 0.6 & 33.4 \\
\hline 2015 & 83.4 & 80.7 & 89.9 & 81.8 \\
\hline 2017 & 72.4 & 85.2 & 52.6 & 15.7 \\
\hline \multicolumn{5}{|c|}{ Average change per year (percentage points) } \\
\hline $1970-2000$ & 0.51 & 0.07 & 0.32 & 1.40 \\
\hline $2000-2017$ & 1.19 & 2.35 & 0.33 & -2.19 \\
\hline $1970-2017$ & 0.76 & 0.89 & 0.33 & 0.10 \\
\hline
\end{tabular}

Notes: The figures show the loan-to-value ratio, defined as the ratio of new housing loans to land/housing purchases (percent).

Source: Family and Income Expenditure Survey, conducted by the Statistics Bureau, Ministry of Internal Affairs and Communications, Government of Japan

Table 3: Homeownership Rate (percent)

\begin{tabular}{|c|c|c|c|c|}
\hline Year & Full sample & 30-39 & $40-49$ & $50-59$ \\
\hline & & age group & age group & age group \\
\hline 1975 & 56.4 & 47.9 & 64.6 & 75.5 \\
\hline 1980 & 61.2 & 48.9 & 70.3 & 83.4 \\
\hline 1985 & 65.0 & 46.9 & 73.8 & 85.8 \\
\hline 1990 & 66.0 & 42.4 & 73.7 & 81.4 \\
\hline 1995 & 64.1 & 39.1 & 67.8 & 82.0 \\
\hline 2000 & 68.5 & 44.2 & 75.6 & 84.6 \\
\hline 2005 & 68.8 & 46.2 & 72.3 & 84.2 \\
\hline 2010 & 71.2 & 51.8 & 73.8 & 83.7 \\
\hline 2015 & 76.0 & 58.3 & 77.1 & 85.1 \\
\hline 2017 & 79.0 & 62.2 & 79.1 & 87.0 \\
\hline \multicolumn{5}{|c|}{ Average change per year (percentage points) } \\
\hline $1975-2000$ & 0.48 & -0.15 & 0.44 & 0.37 \\
\hline $2000-2017$ & 0.62 & 1.06 & 0.21 & 0.14 \\
\hline $1975-2017$ & 0.54 & 0.34 & 0.35 & 0.27 \\
\hline
\end{tabular}

Notes: The figures show the homeownership rate (percent).

Source: Family and Income Expenditure Survey, conducted by the Statistics

Bureau. Ministry of Internal Affairs and Communications. Government of Japan 
Table 4: Ratio of Land/Housing Purchases to Household Disposable Income (percent)

\begin{tabular}{|l|r|r|r|r|}
\hline \multicolumn{1}{|c|}{ Year } & Full sample & \multicolumn{2}{c|}{$\begin{array}{l}\text { 30-39 } \\
\text { age group }\end{array}$} & \multicolumn{2}{c|}{$\begin{array}{l}\text { age } 49 \\
\text { agroup }\end{array}$} \\
\hline 1970 & & 2.5 & 1.6 & age group \\
\hline 1975 & 2.2 & 4.0 & 2.5 & 2.9 \\
\hline 1980 & 3.4 & 4.7 & 5.3 & 3.8 \\
\hline 1985 & 3.9 & 3.3 & 3.4 & 1.8 \\
\hline 1990 & 3.3 & 2.9 & 2.3 & 2.5 \\
\hline 1995 & 2.3 & 6.9 & 4.9 & 2.1 \\
\hline 2000 & 4.4 & 3.7 & 2.0 & 3.1 \\
\hline 2005 & 2.9 & 1.9 & 2.4 & 3.0 \\
\hline 2010 & 3.2 & 6.4 & 0.5 & 3.0 \\
\hline 2015 & 1.9 & 7.5 & 2.6 & 0.9 \\
\hline 2017 & 2.8 & 7.5 & 0.5 & 1.8 \\
\hline & 1.8 & 0.04 & 0.01 & 0.3 \\
\hline $1970-2000$ & Average change per year (percentage points) & 0.00 \\
\hline $2000-2017$ & 0.02 & 0.22 & -0.09 & -0.16 \\
\hline $1970-2017$ & -0.06 & 0.11 & -0.02 & -0.06 \\
\hline
\end{tabular}

Notes: The figures show the ratio of land/housing purchases to household disposable income (percent).

Source: Family and Income Expenditure Survey, conducted by the Statistics Bureau, Ministry of Internal Affairs and Communications, Government of Japan

Table 5: Ratio of Housing-related Liabilities to House hold Disposable Income by Birth Cohort (percent)

\begin{tabular}{|c|c|c|c|}
\hline \multirow{2}{*}{ Birth years of cohort } & \multicolumn{3}{|c|}{ Age group } \\
\hline & $30-39$ & $40-49$ & $50-59$ \\
\hline $1916-25$ & & & 20.1 \\
\hline $1926-35$ & & 26.1 & 40.2 \\
\hline $1936-45$ & 27.1 & 58.3 & 60.4 \\
\hline $1946-55$ & 62.9 & 80.9 & 78.1 \\
\hline $1956-65$ & 86.1 & 134.7 & 92.7 \\
\hline $1966-75$ & 140.4 & 183.0 & \\
\hline $1976-85$ & 200.7 & & \\
\hline
\end{tabular}

Notes: The figures show the ratio of housing-related liabilities to household disposable income (percent).

Source: Table 1 
Table 6: Ratio of Housing Loan Repayments to Household Disposable Income (percent)

\begin{tabular}{|l|r|r|r|r|}
\hline \multicolumn{1}{|c|}{ Year } & Full sample & \multicolumn{1}{c}{$\begin{array}{c}\text { 30-39 } \\
\text { age group }\end{array}$} & $\begin{array}{r}\text { 40-49 } \\
\text { age group }\end{array}$ \\
\hline 1970 & & 1.4 & 1.3 & age group \\
\hline 1975 & 1.2 & 2.4 & 2.5 & 0.8 \\
\hline 1980 & 2.1 & 3.9 & 5.0 & 1.4 \\
\hline 1985 & 3.9 & 5.3 & 6.5 & 3.3 \\
\hline 1990 & 5.4 & 4.6 & 6.7 & 5.0 \\
\hline 1995 & 5.2 & 5.8 & 7.3 & 5.0 \\
\hline 2000 & 6.1 & 7.4 & 10.1 & 6.2 \\
\hline 2005 & 7.3 & 7.9 & 9.2 & 6.3 \\
\hline 2010 & 7.4 & 8.7 & 10.9 & 6.7 \\
\hline 2015 & 8.8 & 9.6 & 10.7 & 8.6 \\
\hline 2017 & 8.7 & 9.5 & 10.0 & 8.2 \\
\hline & 8.3 & 0.20 & 0.29 & 8.0 \\
\hline $1970-2000$ & Average change per year (percentage points) & 0.18 \\
\hline $2000-2017$ & 0.21 & 0.12 & -0.01 & 0.10 \\
\hline $1970-2017$ & 0.06 & 0.17 & 0.18 & 0.15 \\
\hline
\end{tabular}

Notes: The figures show the ratio of housing loan repayments to household disposable income (percent).

Source: Family and Income Expenditure Survey, conducted by the Statistics Bureau, Ministry of Internal Affairs and Communications, Government of Japan 
Table 7: Ratio of Rent to Household Disposable Income (percent)

\begin{tabular}{|c|c|c|c|c|}
\hline Year & Full sample & $30-39$ & $40-49$ & $50-59$ \\
\hline & & age group & age group & age group \\
\hline 1970 & 2.5 & 3.5 & 1.4 & 1.2 \\
\hline 1975 & 2.2 & 2.7 & 1.3 & 1.0 \\
\hline 1980 & 2.3 & 3.1 & 1.5 & 1.0 \\
\hline 1985 & 2.3 & 3.6 & 1.5 & 1.0 \\
\hline 1990 & 2.4 & 4.2 & 1.7 & 1.0 \\
\hline 1995 & 3.2 & 5.9 & 2.3 & 1.5 \\
\hline 2000 & 3.3 & 6.2 & 2.2 & 1.5 \\
\hline 2005 & 3.5 & 6.5 & 2.7 & 1.8 \\
\hline 2010 & 3.3 & 5.7 & 2.7 & 1.9 \\
\hline 2015 & 3.0 & 5.3 & 2.6 & 1.8 \\
\hline 2017 & 2.6 & 4.9 & 2.3 & 1.8 \\
\hline \multicolumn{5}{|c|}{ Average change per year (percentage points) } \\
\hline $1970-2000$ & 0.03 & 0.09 & 0.03 & 0.01 \\
\hline $2000-2017$ & -0.04 & -0.08 & 0.01 & 0.01 \\
\hline $1970-2017$ & 0.00 & 0.03 & 0.02 & 0.01 \\
\hline
\end{tabular}

Notes: The figures show the ratio of rent to household disposable income (percent). Source: Family and Income Expenditure Survey, conducted by the Statistics Bureau, Ministry of Internal Affairs and Communications. Government of Japan

Table 8: Ratio of Housing-related Expenditures to Household Disposable Income (percent)

\begin{tabular}{|c|c|c|c|c|}
\hline Year & Full sample & $30-39$ & $40-49$ & $50-59$ \\
\hline & & age group & age group & age group \\
\hline 1970 & 3.6 & 4.8 & 2.8 & 2.0 \\
\hline 1975 & 4.3 & 5.1 & 3.8 & 2.4 \\
\hline 1980 & 6.2 & 6.9 & 6.5 & 4.4 \\
\hline 1985 & 7.7 & 8.9 & 7.9 & 6.0 \\
\hline 1990 & 7.6 & 8.8 & 8.4 & 6.0 \\
\hline 1995 & 9.4 & 11.6 & 9.6 & 7.7 \\
\hline 2000 & 10.6 & 13.7 & 12.3 & 7.9 \\
\hline 2005 & 10.9 & 14.4 & 11.9 & 8.5 \\
\hline 2010 & 12.0 & 14.3 & 13.6 & 10.5 \\
\hline 2015 & 11.7 & 14.9 & 13.3 & 9.9 \\
\hline 2017 & 11.0 & 14.5 & 12.3 & 9.8 \\
\hline \multicolumn{5}{|c|}{ Average change per year (percentage points) } \\
\hline $1970-2000$ & 0.23 & 0.29 & 0.32 & 0.19 \\
\hline $2000-2017$ & 0.02 & 0.05 & 0.00 & 0.11 \\
\hline $1970-2017$ & 0.16 & 0.21 & 0.20 & 0.16 \\
\hline
\end{tabular}

Notes: The figures show the ratio of housing-related expenditures (the sum of rent and housing loan repayments) to household disposable income (percent).

Source: Family and Income Expenditure Survey, conducted by the Statistics Bureau, Ministry of Internal Affairs and Communications. Government of Japan 
Table 9: Non-Housing Consumption Propensity (percent)

\begin{tabular}{|c|c|c|c|c|}
\hline Year & Full sample & 30-39 & 40-49 & $50-59$ \\
\hline & & age group & age group & age group \\
\hline 1970 & 77.2 & 77.1 & 77.4 & 76.7 \\
\hline 1975 & 74.9 & 74.9 & 74.6 & 74.3 \\
\hline 1980 & 75.7 & 74.5 & 75.9 & 76.8 \\
\hline 1985 & 75.1 & 73.1 & 75.4 & 76.1 \\
\hline 1990 & 72.8 & 68.8 & 74.3 & 73.9 \\
\hline 1995 & 69.3 & 62.8 & 72.4 & 70.2 \\
\hline 2000 & 68.9 & 61.5 & 68.6 & 71.7 \\
\hline 2005 & 71.2 & 62.8 & 69.4 & 74.2 \\
\hline 2010 & 70.8 & 62.6 & 65.7 & 74.7 \\
\hline 2015 & 73.8 & 65.7 & 69.7 & 74.1 \\
\hline 2017 & 69.4 & 59.0 & 64.1 & 73.0 \\
\hline \multicolumn{5}{|c|}{ Average change per year (percentage points) } \\
\hline $1970-2000$ & -0.28 & -0.52 & -0.29 & -0.17 \\
\hline $2000-2017$ & 0.03 & -0.15 & -0.27 & 0.08 \\
\hline $1970-2017$ & -0.17 & -0.39 & -0.28 & -0.08 \\
\hline
\end{tabular}

Notes: The figures show the ratio of financial assets net of non-housing liabilities to household disposable income (percent).

Source: Family and Income Expenditure Survey, conducted by the Statistics Bureau, Ministry of Internal Affairs and Communications, Government of Japan

Table 10: Ratio of Net Financial Assets to Household Disposable Income (percent)

\begin{tabular}{|c|c|c|c|c|}
\hline Year & Full sample & $30-39$ & $40-49$ & $50-59$ \\
\hline & & age group & age group & age group \\
\hline 1970 & 97.9 & 79.2 & 97.3 & 135.8 \\
\hline 1975 & 97.3 & 78.1 & 97.1 & 119.6 \\
\hline 1980 & 125.4 & 98.6 & 117.4 & 163.8 \\
\hline 1985 & 150.2 & 111.2 & 137.8 & 179.3 \\
\hline 1990 & 192.8 & 137.8 & 166.3 & 221.4 \\
\hline 1995 & 212.3 & 136.4 & 175.0 & 251.0 \\
\hline 2000 & 229.0 & 136.4 & 192.9 & 256.1 \\
\hline 2005 & 233.7 & 136.2 & 192.9 & 269.7 \\
\hline 2010 & 231.4 & 122.5 & 177.1 & 270.8 \\
\hline 2015 & 244.2 & 125.5 & 172.6 & 276.5 \\
\hline 2017 & 244.0 & 116.4 & 175.4 & 274.7 \\
\hline \multicolumn{5}{|c|}{ Average change per year (percentage points) } \\
\hline $1970-2000$ & 4.37 & 1.90 & 3.18 & 4.01 \\
\hline $2000-2017$ & 0.88 & -1.17 & -1.03 & 1.09 \\
\hline $1970-2017$ & 3.11 & 0.79 & 1.66 & 2.95 \\
\hline
\end{tabular}

Notes: The figures show the ratio of financial assets net of non-housing liabilities to household disposable income (percent).

Source: Family and Income Expenditure Survey, conducted by the Statistics Bureau, Ministry of Internal Affairs and Communications, Government of Japan 
Table 11: Ratio of Net Financial Assets to Household Disposable Income by Birth Cohort (percent)

\begin{tabular}{|c|c|c|c|c|c|c|}
\hline \multirow[b]{2}{*}{$\begin{array}{c}\text { Birth years of } \\
\text { cohort }\end{array}$} & \multicolumn{6}{|c|}{ Age group } \\
\hline & $30-39$ & $40-49$ & $50-59$ & $\begin{array}{c}\text { Increase from } \\
30-39 \text { to } 40- \\
49 \\
\end{array}$ & $\begin{array}{c}\text { Increase from } \\
40-49 \text { to } 50- \\
59\end{array}$ & $\begin{array}{c}\text { Increase from } \\
30-39 \text { to } 50-59\end{array}$ \\
\hline $1916-25$ & & & 119.6 & & & \\
\hline $1926-35$ & & 97.1 & 179.3 & & 82.1 & \\
\hline $1936-45$ & 78.1 & 137.8 & 251.0 & 59.7 & 113.2 & 172.9 \\
\hline $1946-55$ & 111.2 & 175.0 & 269.7 & 63.8 & 94.7 & 158.5 \\
\hline $1956-65$ & 136.4 & 192.9 & 276.5 & 56.5 & 83.6 & 140.1 \\
\hline $1966-75$ & 136.2 & 172.6 & & 36.4 & & \\
\hline $1976-85$ & 125.5 & & & & & \\
\hline
\end{tabular}

Notes: The figures show the ratio of financial assets net of non-housing liabilities to household disposable income (percent).

Source: Table 10 
Figure 1. The share of various types of housing loans in new lending

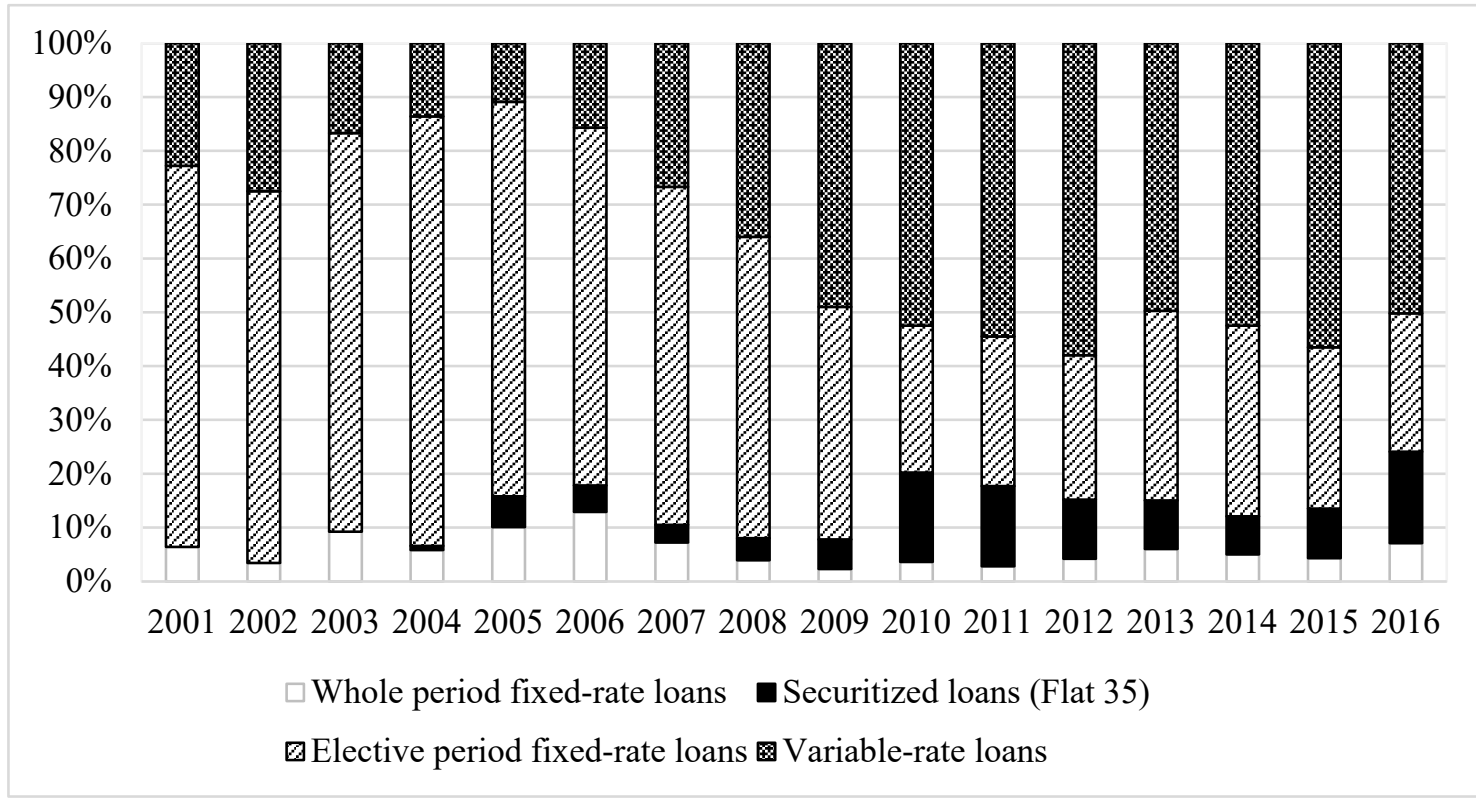

Source: Housing Bureau, Ministry of Land, Infrastructure, Transport and Tourism, various years, Results Report on the Survey on the Status of Private Housing Loans (Minkan Juutaku Ron no Jittai nikansuru Chousa: Kekka Houkokusho) (available at https://www.e-stat.go.jp/statsearch/files?page $=1 \&$ toukei $=00600670 \&$ tstat $=000001016940)$

Figure 2. The level of understanding about the impact of possible interest rate increases on the loan repayment amount

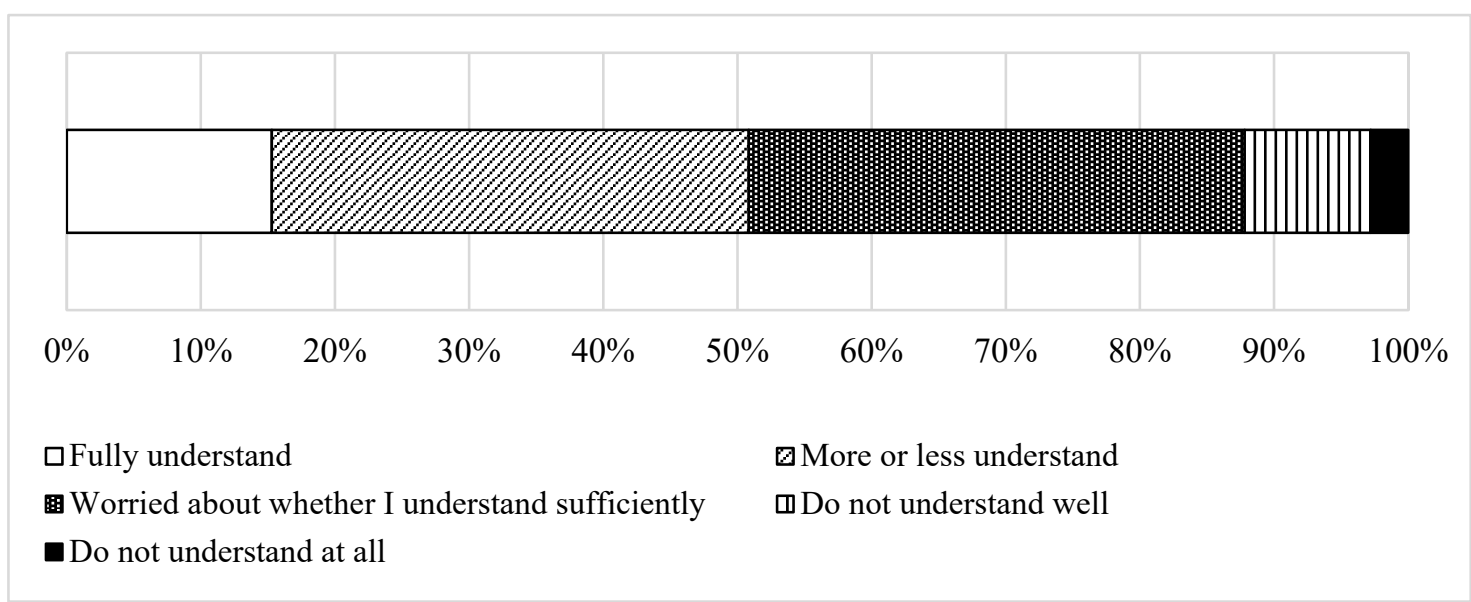

Note: The figures are for those who have taken out variable-rate loans.

Source: Japan Housing Finance Agency (2019), 2018 Survey on the Status of Private Housing Loan Users (2018-nendo Minkan Juutaku Ron Riyousha no Jittai Chousa) (available at https://www.jhf.go.jp/about/research/loan_user.html\#data01) 
Figure 3. Planned response to the increase in the loan repayment amount in the event of interest rate increases

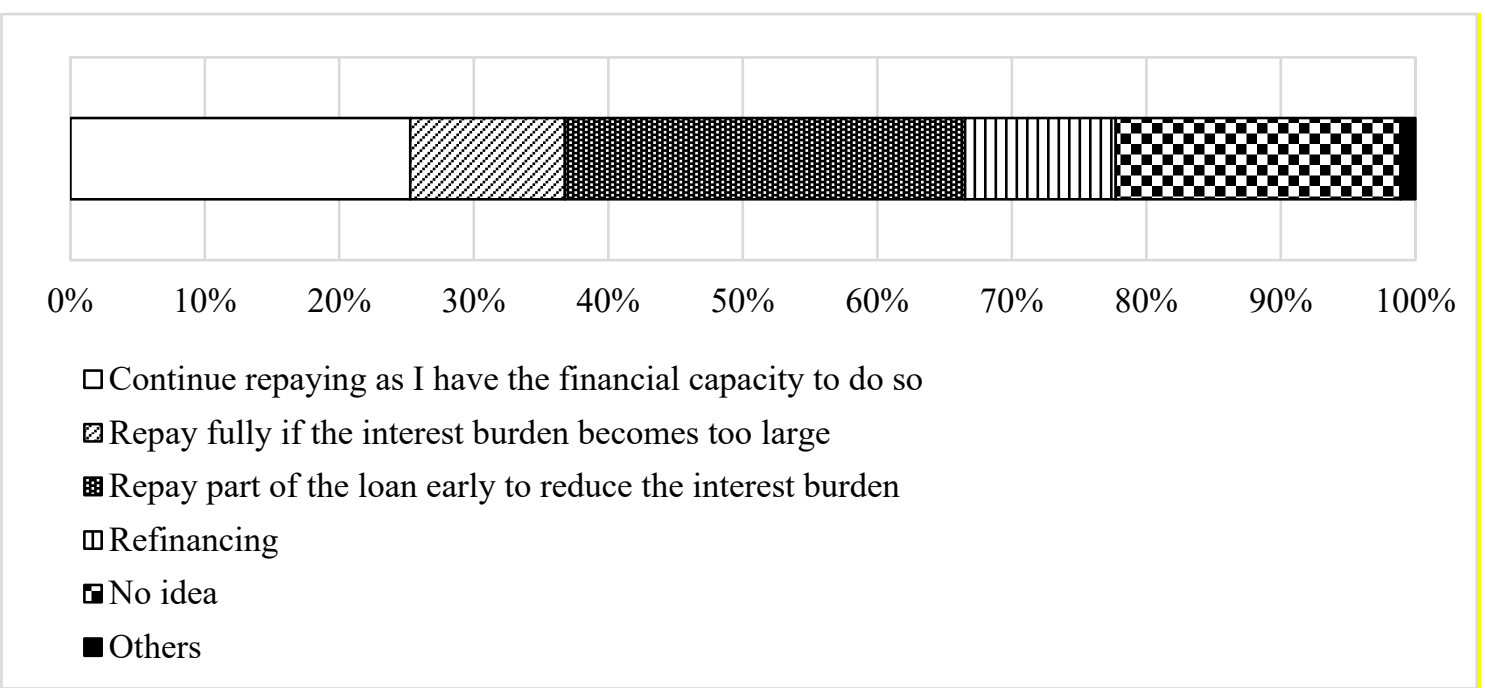

Note: The figures are for those who have taken out variable-rate loans.

Source: Japan Housing Finance Agency (2019), 2018 Survey on the Status of Private Housing Loan Users (2018-nendo Minkan Juutaku Ron Riyousha no Jittai Chousa) (available at https://www.jhf.go.jp/about/research/loan_user.html\#data01) 